\title{
Editorial
}

\section{Photovoltaic Materials and Devices 2013}

\author{
Bhushan Sopori, ${ }^{1}$ Keith Emery, ${ }^{1}$ Peter Rupnowski, ${ }^{2}$ and Sudhakar Shet ${ }^{3}$ \\ ${ }^{1}$ National Renewable Energy Laboratory, 1617 Cole Boulevard, Golden, CO 80401, USA \\ ${ }^{2}$ Solar Energy Consultant, Midland, MI 48686, USA \\ ${ }^{3}$ Princeton Optronics, Trenton, NJ 08619, USA
}

Correspondence should be addressed to Bhushan Sopori; bhushan.sopori@nrel.gov

Received 14 November 2013; Accepted 14 November 2013

Copyright (c) 2013 Bhushan Sopori et al. This is an open access article distributed under the Creative Commons Attribution License, which permits unrestricted use, distribution, and reproduction in any medium, provided the original work is properly cited.

Photovoltaic energy has now gained acceptance from most of the electrical energy users for both the residential and the commercial applications. Concomitantly, the production of PV energy has been steadily increasing. Likewise there is an enormous expansion of the PV research community, with PV becoming a mainstream educational topic both as general course work and as research field at universities and academic institutions. While new areas of PV research are continually being fostered, the silicon manufacturing technology has retained a dominant role through availability of lower cost poly, advances in the crystal growth technologies that led to higher quality wafers, advances in the wafering technology, and new cell processing methods. Reduction in cost has placed a renewed emphasis on the development of higher efficiency devices-based on $n$-type Si and using architectures suitable for thinner, passivated devices. Likewise, growth in production volume and improvements in the module efficiencies of commercial CdTe and CIGS modules have been further lowering their costs. However, there are still many challenges in both R\&D and commercialization of PV modules in areas that include new cell designs, commercial manufacturing equipment, and implementation of online monitoring technologies.

This second special issue serves as a timely publication bringing the latest results of various PV technologies. It includes a collection of 22 peer-reviewed papers encompassing all areas of PV fields. We hope that readers find them interesting as well as of help in their research work.

\section{Acknowledgments}

The editors acknowledge with thanks the contributing authors for submitting their manuscripts and the reviewers for ensuring high quality of the published papers.

Bhushan Sopori Keith Emery

Peter Rupnowski Sudhakar Shet 

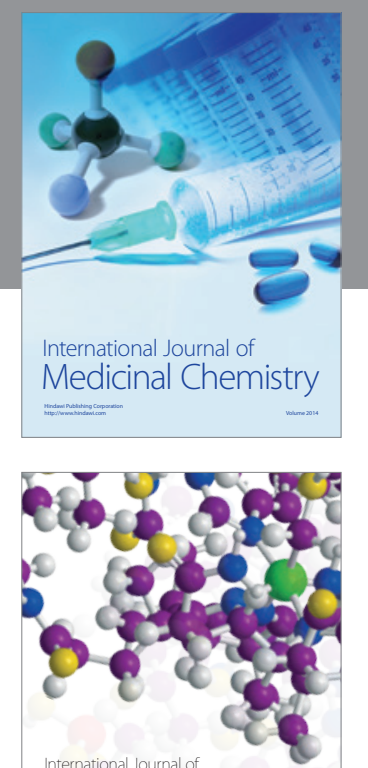

\section{Carbohydrate} Chemistry

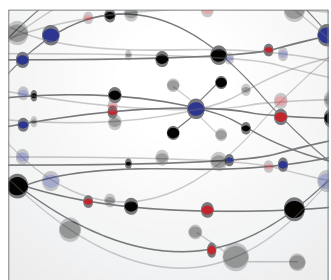

The Scientific World Journal
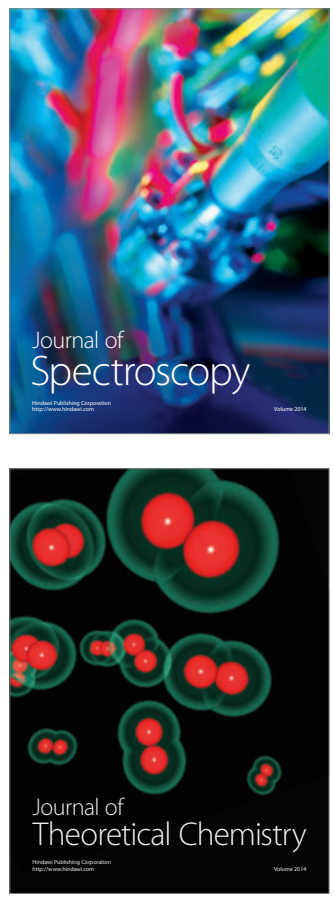
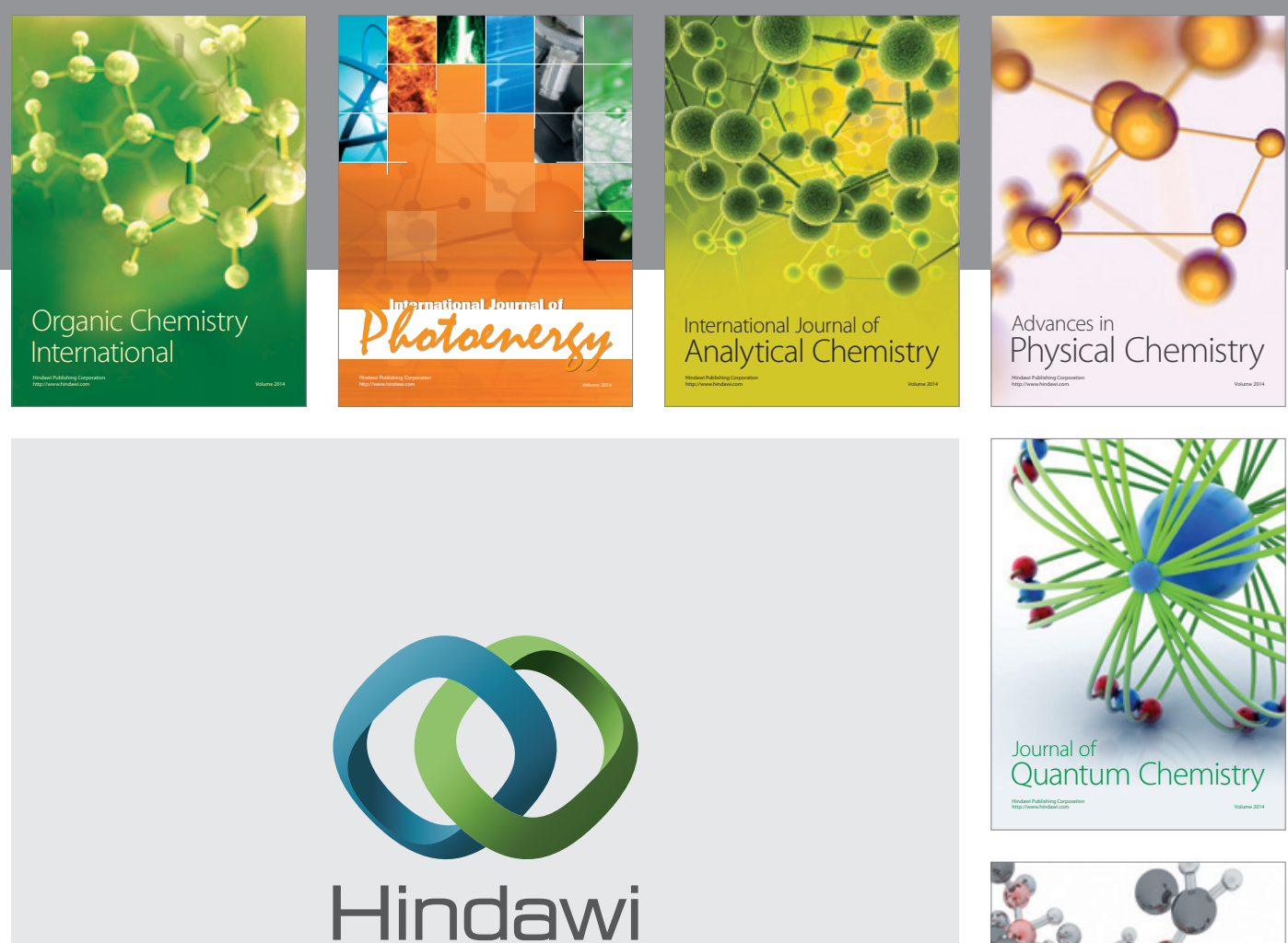

Submit your manuscripts at

http://www.hindawi.com

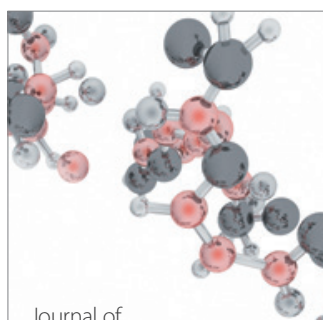

Analytical Methods

in Chemistry

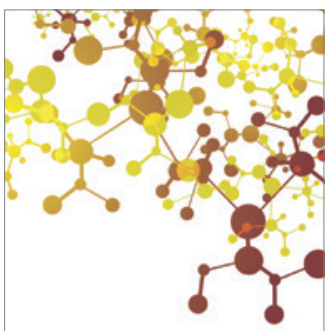

Journal of

Applied Chemistry

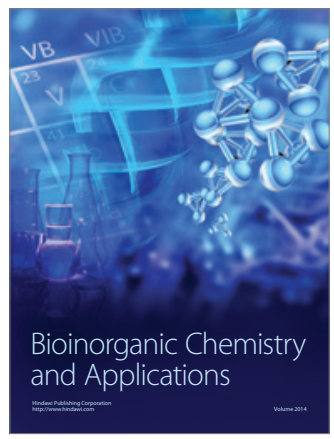

Inorganic Chemistry
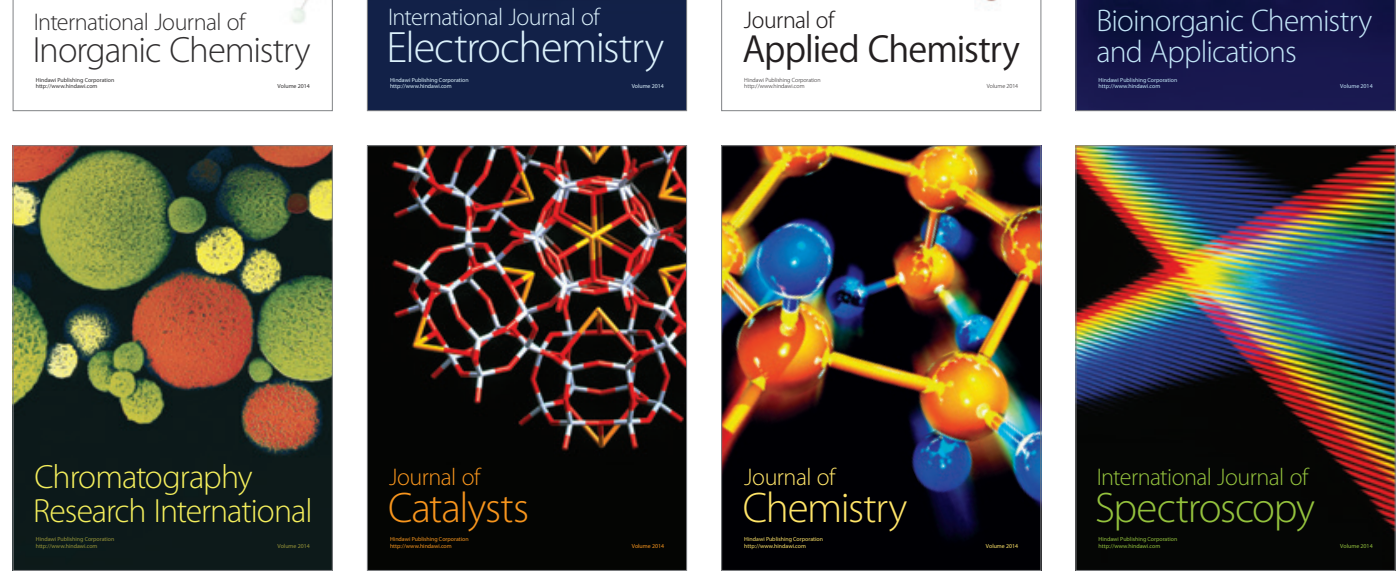